\title{
Örgütsel Vatandaşlık ve Örgütsel Yabancılaşma Arasındaki İlişkide İş Zenginleştirmenin Aracılık Etkisi
}

DOI: 10.26466/opus.620697

*

\author{
Kemal Eroğluer * \\ * Dr.Öğr. Üyesi, Milli Savunma Üniversitesi, Kara Harp Okulu, Çankaya / Ankara /Türkiye \\ E-Posta: erogluer@yahoo.com.tr \\ ORCID: 0000-0002-2456-5140
}

Öz

Literatürde örgütsel yabancılaşma kavramı üzerinde, örgütsel vatandaşlık ve iş zenginleştirme kavramlarmın etkisinin olduğu bilinmektedir. Her bir faktörün etkisinin sabit olarak kabul edildiği bir ortamda, örgütsel yabancılaşma kavramı üzerinde örgütsel vatandaşlık kavramı ters orantılı ve iş zenginleştirme kavramı ise doğru orantılı olarak etkili olduğu değerlendirilir. Literatürde yapılan inceleme sonucunda çeşitli araştırmacilar tarafindan örgütsel vatandaşlık, örgütsel yabancilaşma ve iş zenginleştirme kavramları arasındaki ilişkinin araştırıldığ belirlenmiş, ancak örgütsel yabancılaşma kavramı ile örgütsel vatandaşlık kavramı arasındaki ilişkide iş zenginleştirme kavramının aracılık etkisinin araştıılmadı̆̆ı tespit edilmiştir. Bu kapsamda yapılan çalışmanın amacl, örgütsel vatandaşlık davranışının örgütsel yabancılaşma üzerindeki etkisi ve bu etkide iş zenginleştirmenin aracilı rolünün olup olmadı̆̆ın belirlemektir. Söz konusu çalışmada kullanılan veriler, Kırıkkale ilinde bulunan MKE Pirinç Fabrikası Müdürlü̈̆̈̈nün personeline uygulanan ü̧̈ adet ölçek ile toplanmış ve kurulan modelin analizi Yapısal Eşittik Modellemesi (YEM) ile test edilmiştir. Çalışma evrenini fabrikada görev yapan 217 çalışan oluşturmuştur. Yapılan çalışma sonucunda, iş zenginleştirme kavramının örgütsel vatandaşlık ile örgütsel yabancılaşma arasındaki ilişkide kısmi aracılık rolüne sahip olduğu ve yapılan Sobel Testi sonucunda anlamlı bir ilişkinin bulunduğu belirlenmiştir.

Anahtar Kelimeler: Örgütsel Vatandaşlık; Örgütsel Yalnızlık; İş Zenginleştirme; Aracılık Rolü. 


\title{
The Effect of Job Enrichment as a Mediator Role on Relationship between Organizational Citizenship and Organizational Alienation
}

\begin{abstract}
In the literature, it is known that organizational citizenship and job enrichment have an effect on organizational alienation. Ceteris paribus, organizational citizenship is inversely proportion to organizational alienation and job enrichment is proportion to organizational alienation. In the literature, many researchers have investigated relationship between organizational alienation, organizational citizenship and job enrichment, however, it hasn't been investigated whether job enrichment has any mediating effect in the relationship between organizational citizenship and organizational alienation or not. In this context, the aim of this study is to find the mediating role of job enrichment on relation between organizational alienation and organizational citizenship. The data used in this study were collected with three scales applied to the personnel of the MKE Brass Factory Directorate in Kirikkale province and the analysis of the established model was tested by Structural Equation Modeling (SEM). Three scales were applied to 217 employees at the factory. At the end of the study, it is concluded that job enrichment has a partial mediation role between organizational citizenship and organizational alienation. And it was also found in the Sobel Test that there was a meaningful relationship between organizational citizenship and organizational alienation. Therefore it is found that there was a partial mediating effect in relationship between two variables
\end{abstract}

Keywords: Organizational Citizenship, Organizational Alienation, Job Enrichment, Mediation. 


\section{Giriş}

Örgütlerin sahip olduğu en önemli sermaye çalışanlarıdır. Örgüte hayat veren, onu canlandıran, işlevsel hale getiren, amaçlarını gerçekleştirmek üzere gerekli faaliyetleri bir ahenk içinde, birbirinin tamamlayıcısı olarak koordine eden ve sonuca ulaştıran şüphesiz çalışanlardır.

Günümüzde küreselleşme ile birlikte, bilim ve teknolojideki gelişmeler hayatın her alanını olumlu olduğu kadar olumsuz olarak da etkilemektedir. Toplumsal yaşamın ayrılmaz bir parçası olan örgütler, küreselleşme ile birlikte global pazarın bir aktörü haline gelmişler ve faaliyetlerine devam edebilmek için rekabet etmek zorunda kalmışlardır. Örgütler sürdürülebilir rekabet avantajı için proaktif davranmak zorundadırlar. Örgütler proaktif davranarak ürettikleri mal veya sundukları hizmet ile müşterilerinin beklentilerini karşılamaya çalışırlar. Ancak beklentisini karşılamak zorunda oldukları bir de iç müşterileri vardır ki bunlar örgütün en önemli unsurunu oluşturur. Yaşanan gelişmeler sonucunda, örgütler çalışanları artık bir maliyet unsuru olarak değil, bir katma değer olarak görmektedirler. Bunun için çalışanlara yönelik yapılan maddi iyileştirmeler kadar; çalışanların tatmini, kendilerini örgütün bir parçası olarak görüp değer yaratacakları uygulamaların hayata geçirilmesi, aile bütünlüğü içinde çalışanların yalnız kalmadan görev yapabilecekleri bir iklim yaratmak gibi hususlar örgüt yönetiminin önemli görevleridir.

Bu kapsamda, bu çalışma ile örgütlerde çalışanların örgütsel vatandaşlık davranışının örgütsel yabanclaşma üzerindeki etkisi ve bu etkide iş zenginleştirmenin aracılık rolünü belirlemek amaçlanmıştır. Çalışanların beklenenin üzerinde rol davranışları göstermeleri yönetim ve örgüt için önemli katkılar sağlarken zamanla bu davranışın normal bir davranış olarak kabul edilmesi çalışanlar üzerinde olumsuz etkiler yaratabilir. Çalışmanın önemi bu noktada günümüz şartlarında özellikle teknolojik gelişmeler sonucu örgüt içinde çalışanların giderek yalnızlaşması üzerinde örgütsel vatandaşlık davranışının etkisini ve bu etkide iş zenginleştirmenin rolünün belirlenmesi ile literature katkı sağlayacağı değerlendirilmektedir. 


\section{Kavramsal Çerçeve}

Örgütsel yaşamda çalışanlar açısından iki uç noktadan bahsedilebilir. İlki olumlu yönde örgütü benimsemek, kendini örgütün bir parçası olarak görmek, diğeri ise olumsuz yönde çeşitli nedenlerle örgütle arasındaki duygusal bağı koparmak veya bir bağ kuramamak, ona yabancılaşmaktır. Örgüt açısından önemli bir değer olduğu kadar, yaşadığı olumsuzluklar sonucu yerine göre önemli bir maliyet kalemi de olabilen çalışanlardan en üst seviyede yararlanırken; eş zamanlı olarak onların maddi ve manevi boyutta beklentilerini karşılamak, onları motive etmek, örgütün bir parçası olarak çalışmalarını sağlamak yönetimin izleyeceği politika ve uygulamalara bağlıdır.

\section{Örgütsel Vatandaşlik}

Örgütsel vatandaşlık davranışı (ÖVD) kavramının gelişimi iki dönem halinde incelenmektedir. Birinci dönem 1930'larda başlayıp ve 1980'lere kadar devam ederken, diğer dönem ise 1980'lerden itibaren günümüze kadar devam eden bir süreçtir. Bu noktada ÖVD'nın temellerinin Barnard'ın düşünceleri ve Hawthorne deneylerinin sonuçları ile ilgili çalışmalar yapan Roethlisberger ve Dickson'un çalışmalarına dayandığı, ancak Katz ile Kahn'ın "The Social Psychology of Organizations" başlıklı çalışmalarında ortaya attıkları fikirlerin, "açı sisteme dayalı örgüt modeli ile örgütsel vatandaşlık davranışı" nun başlangıcı olarak kabul edilmektedir. Organ ve Bateman'ın (1983) çalışmalarında ise ÖVD'nın ilk defa kavram olarak kullanıldığı belirtilmiştir (Karaaslan vd., 2009, s.137).

ÖVD, örgütte belirlenen rol gereklerinin ötesinde ve örgütün amaçlarını gerçekleştirmek için çalışan, birim veya bölüm olarak davranışların örgüte adanması olarak tanımlanmıştır (Somech ve Drach-Zahavy, 2000; Feather ve Rauther, 2004). ÖVD'de ekstra rol davranışının üç özelliği vardır. Bunlardan birincisi davranışın işin gereklerinden ziyade gönüllü olarak yapılması, ikincisi davranışın kolayca gerçekleşmemesi yanında örgüte yönelik ve örgüte yarar sağlayan davranış olması, üçüncüsü ise ÖVD'nin çok boyutlu olmasıdır.

Barnard ÖVD'nı çalışanların yapmak zorunda oldukları davranışın ötesinde ekstra sergiledikleri rol davranışı olarak ifade etmiştir (Çetin, 2004, s.3). Organ (1988) ÖVD'nı çalışanların kendi rızasıyla yaptığı davranışlar 
arasında, örgütün etkinliğini artırmayı amaçlayan ve rol gerekleri içinde yer almayan bireysel davranışlar olarak tanımlamıştır. ÖVD'nın resmi iş tanımının bir parçası olmayan olumlu davranış türlerinden oluştuğu ve rol dışı davranışlarla sınırlı tutulması gerektiğini belirtmiştir.

Bateman ve Organ (1983, s.591) ÖVD'nı askeri sistem içinde görevlerin ötesinde sergilenen özverili davranışlardan esinlenerek "İyi Asker Sendromu" (Good Soldier Syndrome) şeklinde betimlemişlerdir. Zira araştırmacıların da belirttiği gibi ÖVD formel iş davranışlarından daha fazlasını içermekte, örgütü korumaktan, örgütün başarısını arttırmaya kadar görev tanımında yer almayan pek çok davranışı kapsamaktadır (Şanal, 2013, s.531).

ÖVD'na yönelik yapılan tanımlar incelendiğinde, sergilenen bu tür davranışların çalışanlar tarafından örgütte isteyerek ve gönüllü bir şekilde yapılması gerektiğinden daha fazla davranışlar olduğu ve bu davranışların örgütün etkinliğine sağladığ görülmektedir (Sezgin, 2005, s.319). Örgütsel vatandaşlık davranışını benzer davranışlardan ayırt etmek için davranışın gönüllü olarak yapılması, örgüt ve çalışanları açısından yarar sağlaması ve kabul edilmesi niteliklerini taşıması gerekir ve onu benzer olumlu davranışlardan ayırır (Özdevecioğlu, 2003, s.118).

ÖVD yapılan araştırmalarda beş boyutlu olarak incelenmiştir. Bu çalışmada da literatüre uygun olarak en çok kabul gören Organ'ın (1988) beş boyutlu sınıflandırması kullanılacaktır. Bu boyutlar kısaca şu şekilde açıklanabilir;

Özgecilik: Özgecilik davranışını; Organ (1988) çalışanların örgüte yönelik faaliyetlerde diğer çalışanlara nazaran karşllık beklemeksizin sergiledikleri gönüllü davranışlar, Penner vd. (1997), iş ile ilgili sorunu olan çalışana yardım etmek için yapılan gönüllü davranışlar, Allison vd. (2001) ise çalışanların yapacakları işe yönelik cihazları kullanmalarına, işlerini bitirmelerine, ihtiyaçları olan bilgiye ulaşma yollarına, sorumlu oldukları bir görevi zamanında hazırlamalarına yardım eden davranışlar olarak tanımlamışlardır.

Görev Bilinci: Bilinçlilik veya vicdanlılık olarak da ifade edilen görev bilinci, çalışanın işe ilişkin rolünü ya da görevini asgari seviyeden daha fazlasını yapmaya yönelten davranışları belirtir. Bu kapsamda işe devamlılık, etkili çalışma zamanı yönetimi, kurallara bağlı olma ve uymaya dikkat etmeyi 
ifade eder (Sezgin, 2005, s.324). Görev bilincine sahip çalışanlar işyeri kurallarını kendi irade ve istekleri ile benimserler. Sergiledikleri davranışlarında etik ve ahlaki kurallara uyarlar ve çevrelerine yardım etmeyi severler (Barksdale ve Werner, 2001, s.145-155).

Nezaket: Nezaket, örgütte faaliyetler ve işleyiş esnasında çalışanların görevlerin ifası ve kararların alım sürecinde birbirleri ile olan ilişkilerinde uyarma, danışma ve hatırlatma gibi davranışlar sergilemeleri şeklinde ifade edilmiştir (Organ, 1988, s.47). Toplum içinde davranışları düzenleyen nezaket kuralları, aynı zamanda duygusal istikrarı korur ve muhtemel çatışmaları önler. Örgüt içinde özellikle yapılacak işlerle ilgili önceden koordinasyonu sağlayarak işlerin planlanmasını ve icrasını kolaylaştırır (İşbaş1, 2000, s.29).

Centilmenlik: Centilmenlik davranışı, örgüt içinden veya dışından ilişki içinde bulunulan her kesim ile yaşanan olumsuzlukların rahatsızlık duyulmadan hoşgörü ile karşılanmasıdır (Podsakoff vd., 2000, s.515). Çalışanların örgüt yönetime kendi istekleri ile katılmalarını ve kendilerini örgütün önemli bir parçası olarak kabul etmelerini ifade eder (George ve Brief, 1992, s.310-339; Allison vd., 2001, s.284)

Erdemlilik: Erdemlilik, çalışanların örgütün yaşamına ve faaliyetlerine sorumluluk sahibi olarak aktif katılımını, daha genel olarak bağlılığını ve alakasını gösteren davranışlardır (Podsakoff vd., 2000, s.1525). Sivil erdem olarak da adlandırılan erdemlilik, örgütün çıarlarını en üst seviyede koruma, örgütün işleyişini destekleme, kendi rızasıyla faaliyetlere iştirak etme ve örgütle ilgili olma davranışları olarak da ifade edilmiştir (Sezgin, 2005, s.323).

\section{Örgütsel Yabancılaşma}

Latincede "alienatio" yabancılaşma-yabancilaştırma anlamına gelmektedir. Türkçeye girişi ise Farsça "boş ve 1sısız yer" anlamındaki "yaban" kelimesinden türetilmiş ve "yabancılaşma" şeklinde kullanılmaya başlanmıştır (Kiraz, 2011, s.148). Kelime ilk olarak dinsel olarak putperestlikle ilgili kullanılmış, felsefi anlamda ilk kez Hegel tarafından "mutlak varlığın özünden kopması 
ve sonra tekrar özüne dönmesi" olarak ifade edilmiş, Marx ise yabancılaşmayı kapitalist sistemle değerlendirmiş, değişim değerinin daha önemli hale gelmesi nedeniyle çalışanın "emeğe, kendine ve topluma yabancılaşması olarak kullanılmıştır (Salihoğlu, 2014, s.3).

Yabancılaşma, Şimşek vd., (2008, s.314) tarafından kişinin içinde bulunduğu çevre ile olan uyumunun azalması, çevre üzerindeki kontrol gücünün etkisini kaybetmesi ile kişinin yaşadığı durumlar karşısında kendisini çaresiz ve yalnız hissetmesi olarak tanımlanmıştır.

Örgütlerde çalışanların etkinliği ve verimliliği büyük oranda örgütü ile olan ilişkisine bağlıdır. Örgüt ile olan ilişkisinin zayıflaması, çalışanın kendisini geri çekmesi, yetkinliklerini örgüt ile paylaşmaması, örgüt ile arasındaki bağı zayıflatarak örgüte karşı yabancılaşmasına neden olabileceği belirtilmiştir (Zengin ve Kaygın, 2016, s.394). Çalışanın örgüte yabancılaşması işinden soğuması ve uzaklaşması, örgüte olan bağlılığının azalması ile kendini gösterir ve zamanla performans ve başarısı azalır.

Froom (1991, s.125), yabancılaşma kavramını bir hastalık olarak nitelemiş, bireyin kendisini bulunduğu çevreden ve diğer bireylerden ayırması, yalnızlaşması ve yabancılık hissetmesi olarak tanımlamıştır. Wattz (1982, s.128) ise yabancılaşmayı insanın kendi yarattığı teknolojilerden, içinde bulunduğu sosyal yapı ve kurumlardan ve çevresinde bulunan diğer insanlardan kopması olarak tanımlamıştır.

Örgütsel yabancilaşmaya (ÖY) neden olan etkenler, Demirel ve Ünal (2011, s.3) tarafından örgütsel ve çevresel olmak üzere iki grupta incelenmiştir. Örgütsel faktörler arasında yönetim tarzı, deneyim, örgütün yapısı, büyüklügüu, üretim metotları, iş bölümü, çalışma şartları ve iletişim siralanırken, çevresel faktörler arasında ekonomik, teknolojik, sosyal ve kültürel yapı yanında politik ve hukuki sistem, sanayileşme derecesi ve kitle iletişim araçları sayılmıştır (Salihoğlu, 2014, s.4).

Örgütlerde yabanclaşmanın ana nedeni Örnek ve Aydın (2008, s.207) tarafından çalışma ortamının çalışanı tatmin etmemesi ve bu tatminsizlikten kaynaklanan stres olarak belirtilmiştir. Örgütlerdeki yetersiz ve olumsuz çalışma koşulları çalışanların yabancılaşmasına neden olmakta, çalışanlar işi sadece para kazanma aracı olarak görmektedir. Olumsuz duygulara sahip olan çalışanların beklentileri kalmadığından, bu durum onların örgütün amaçlarına yönelik çaba göstermemelerine yol açmaktadır. 
Seeman, yabancılaşma ile ilgili 1959 yılında yaptığı çalışmasında yabancılaşmayı "güçsüzlük", "anlamsızlık", "normsuzluk", "çevreden uzaklaşma" ve "kendine yabancılaşma" olarak üzere beş farklı boyutta incelemiştir. Buna karşın Feuer ise yabancılaşma konusunu, "sınıflı toplumun yabancılaşması", "rekabetçi toplumun yabancılaşması", "endüstriyel toplumun yabancilaşması", "insan toplumunun yabancilaşması", "irkın yabancılaşması" ve "kuşakların yabancılaşması" boyutlarıyla incelemiştir (Fettahlıŏlu, 2006, s.31).

Güçsüzlük: Kişinin, davranışının ulaşmak istediği amaçları elde etmesine yardım etmeyeceği veya bu amaca ulaşmada istediği yardımı bulamayacağına dair olumsuz algı ve beklentilerinin yarattı̆̆ı duygudur (Yeniçeri, 2009, s.142). Örgütlerde çalışanların yetersizlik duygusu, yönetim ve örgüt yapısından ve işleyişinden kaynaklanan problemler, teknolojik gelişmeler, iletişim alanında yaşanan gelişmeler ile çalışanların sahip oldukları kapasitelerin gelişmeler karşısında yetersiz kalması çalışanların güçsüzlük hissetmesine neden olan etkenlerdir (Zengin ve Kaygin, 2016, s.394).

Anlamsızlık: Kişinin göstereceği davranışları tahmin etmesine yardımcı olacak kalıpları analiz edemediği zaman ortaya çıkan ve kişinin neye inanması gerektiğini bilemediği veya karar veremediği durumu ifade eder (Yeniçeri, 2009, s.142). Benzer bir tanımda da kişinin neye inanması gerektiğini anlayamaması, toplumda kabul gören ve doğru olarak nitelendirilen bilgi, davranış veya tutumların kişi için bir anlamının olmaması ve kişiyi bir sonuca götürmeyeceğine olan inancı olarak ifade edilmiştir (Özler ve Dirican, 2014, s.293).

Normsuzluk: Kuralsızlık veya standartların olmaması olarak da adlandırılan normsuzluk boyutu, kişinin davranışların belirleyecek ve yönlendirecek kalıplar, kurallar ve ilkeler bulamaması nedeniyle toplumun onaylamadığı yöntem ve davranışlarla hedefini elde etmeye çalışmasıdır (Şimşek vd., 2008, s.316). Kişiler toplumun kurallarını hiçe sayarak kendi amaçlarına ulaşmak için ahlaki ve etik dışı her türlü yolu deneyebilirler (Zengin ve Kaygın, 2016, s.396). Normsuzluk beraberinde Makyavellist davranışları getirebilir. 
Çevreden uzaklaşma: Bu boyut soyutlanma olarak da adlandırılır. Kişinin içinde bulunduğu çevreden kaçması, diğer kişilerle ilişki kurmak istememesi, ilişki kursa bile bunu asgari müşterekte tutması çevreden uzaklaşmasını ifade eder. Bu davranış şekilleri kişinin psikolojik durumundan kaynaklandığı gibi, çevresinden de kaynaklanabilir (Elma, 2003, s.35; Yalçın ve Koyuncu, 2014, s.87-88).

Kendinden uzaklaşma: Kendinden uzaklaşma bireyin sahip olduğu gücün farkında olmaması anlamına gelmektedir. Seeman (1983:176), örgütlerde çalışanların sergiledikleri kendinden uzaklaşma davranışının iki yönlü olduğunu ifade etmiştir. Illk olarak çalışanın kendisini iş ortamında gösterememesini, ikinci olarak da yaptığı işin onun için içsel bir anlam ifade etmediğini, kendinden uzaklaşan çalışanların işten ziyade para ve iş güvenliği gibi maddi unsurlara yöneldiğini, bu tür çalışanların yaptıkları işten tatmin sağlamadıklarını belirtmiştir (Özler ve Dirican, 2014, s.293).

Yapılan çalışmada ise Dean (1961) tarafından geliştirilen ve üç boyuttan oluşan Örgütsel Yabancılaşma Ölçeği kullanılmıştır.

\section{İş Zenginleştirme}

1900'lü yılların başından itibaren üretim metotlarındaki gelişme, müşteri taleplerindeki artış ve teknolojik gelişmeler üretimin arttırılmasını sağlayan etkenler olmuştur. Dönemin özelliği itibariyle çalışandan ziyade üretim miktarı ön planda tutulmuştur. Hawtorne deneyleri ile birlikte örgütlerdeki gizli gücün farkına varılmış, yalnızca alınan tedbirlerle üretimin bir noktaya kadar arttırılabileceği anlaşılmış ve insan faktörünün önemi keşfedilmiştir.

1970'li yıllardan itibaren çalışanların moral ve motivasyonlarını arttırma arayışlarında Herzberg ve Davis' in çalışmalarının iş zenginleştirme konusunun başlangıcını oluşturduğu ifade edilir.

İş zenginleştirme (IZ), örgütsel faaliyetlerle ilgili olarak yapılan işlerde çalışanların sorumluluklarını ve başarılarını arttırmaya yönelik yapılan olumlu iyileştirmelerdir. İş zenginleştirme çalışanlara olumlu katkıları olan bir uygulamadır (Eren vd., 2014, s.93). İş zenginleştirme işin büyüme ve ilerleme için daha fazla sorumluluk, tanıma ve imkanlar sunmasıdır (Daft, 2015, s.516). 
İş zenginleştirme özellikle iş tekrar gerektiren bir yapıya sahip ve sıkıcıysa yetenekli çalışanları örgüte çekme, onları motive etme ve elde tutmanın bir yoludur. Bugünün maliyetleri ve rekabetçi şartları göz önüne alındığında iş zenginleştirme, çalışanların motivasyonlarını arttırma ve örgütleri geliştirmede yönetimin önemli bir aracıdır. İşler çalışanları motive etmek ve onların yeteneklerinden daha çok yararlanmak için sorumluluk verilmek suretiyle zenginleştirilir. Beceri çeşitliliğine ihtiyaç duyan çalışanlara daha çok sorumluluk verip onları motive etmek için de iş zenginleştirme uygulamalarına gidilebilmektedir. İş zenginleştirme; iş görevlerinin "dikey" olarak genişletilmesi, çalışanın normalde üst düzey bir çalışan veya amir tarafından yapılan görev ve sorumlulukları yerine getirmesidir. İş zenginleştirme iş görevlerinin planlanması, yürütülmesi ve değerlendirilmesi üzerinde çalışana daha fazla özgürlük ve kontrol sağlar (Choudhary, 2016, s.1020).

İş zenginleştirme kavramı ile iş güçlendirme kavramı ortak noktaları nedeniyle çoğunlukla birbirinin yerine kullanılır. Ancak aralarında belirgin farklar vardır. İş güçlendirme çalışanın zihnine hitap ederken, iş zenginleştirme işin kendisi ile ilgilidir. Güçlendirme çalışan ve yöneticiler arasındaki ilişkilerle ilgiliyken, iş zenginleştirme işe yöneliktir (Bolat, 2008, s.108).

İş zenginleştirmenin; çalışanların tatmin şekli ve iş amaçlarından işin anlamını keşfetmek için zihinlerinde geliştirdikleri bir yaklaşım olduğu ve performanslarını arttırmaya yönelen çalışanların kendilerini gerçekleştirmelerini, öz kontrollerini ve kendilerine olan saygıların arttırabileceği Mclean ve Sims (1978) tarafından ifade edilmiştir. İş zenginleştirme çalışanın işteki motivasyon düzeyini ve performansını arttırırken, çalışanların örgüt hedeflerini gerçekleştirmeye yönelik arzularını da arttırır (Tufail vd., 2017, s.226).

\section{Değişkenler Arası İlişkiler}

Çalışanların moral, motivasyon ve performansları üzerinde önemli etkileri olan örgütsel vatandaşlık davranışı, örgütsel yabancılaşma ve iş zenginleştirme konusunda yapılan çalışmalara kısaca değinilecek olunursa; Meyer, Allen ve Smith (1993), mesleğe yönelik duygusal bağll1ık ile örgütte 
sergilenen gönüllü davranışlar arasında olumlu yönde ilişki olduğunu belirtmişlerdir. Bu çerçevede ÖVD'nın mesleğe olan bağlllık üzerinde olumlu yönde etkisi olduğu ifade edilebilir.

Örgütlerde yabancılaşma duygusu yaşanmasının engellenmesinde veya hafifletilmesinde, yöneticilere oldukça önemli görev düşmektedir (Yalçın ve Koyuncu, 2014, s.93). Yöneticiler, çalışanların yönetime katılımlarını sağlamalı ve daha fazla sorumluluk almaları için teşvik etmeli, gerektiğinde yetki devri yaparak çalışanlara yetki ile birlikte sorumluluk vermeli ve böylece onların güçlendirilmesini sağlamalıdır. Örgütlerde uygulanan yönetim stilleri ve tarzları da çalışanların yabancılaşmasında etkili olabilir. Şimşek vd. (2006, s.575), yöneticinin sergilediği sert tutumun çalışanların yabancılaşması üzerinde etkili olduğunu belirtmişlerdir.

Örgütsel destek ve yabancılaşma konusunda Tanrıverdi ve Kılıç (2016:14) tarafından yapılan çalışmada örgütsel destek algısı arttıkça çalışanların örgütsel vatandaşlık algılarının artacağı ve oluşan olumlu atmosferin etkisiyle çalışanların yabancılaşma düzeylerinin azalacağı ifade edilmiştir.

Dağlı ve Averbek (2017, s.1707) tarafından yapılan araştırmada, örgütsel yabancılaşma ile örgütsel vatandaşılık davranışı arasında negatif yönlü ilişki bulunmuştur. Çalışanların örgütsel vatandaşlık davranışı olumlu yönde geliştikçe, örgütsel yabancılaşma algılarının azaldığı sonucuna ulaşmışlardır. Tummers ve Dulk (2013, s.2) yaptıkları çalışmada özellikle güçsüzlük ve anlamsızlık boyutlarının çalışanlar tarafından olumlu yönde algılanması, diğer bir ifadeyle çalışanın kendini güçsüz hissetmesi ve işi anlamsız bulmasının iş performansı ve iş-aile zenginleşmesi üzerinde olumsuz etkileri olduğunu vurgulamışlardır. Altay ve Dedeoğlu (2016, s.471) tarafından yapılan araştırmada, çalışanların yabancılaşma algılarının örgütsel vatandaşlık davranışının diğergamlık ve sivil erdem boyutlarını olumsuz yönde etkilediğini belirlemişlerdir.

Örgütlerde çalışanlar ile yaptıkları iş arasında uyum sağlandığında, üst seviyede beceri isteyen zenginleştirilmiş işler, motivasyona ve kişisel gelişme ihtiyacı güçlü çalışanlar ile buluştuğunda çalışanların motivasyonları daha da artmaktadır. Yapılan bir çalışmada üst seviyede motivasyona sahip çalışanların sosyal mübadele ilkesine göre daha fazla örgütsel vatandaşlık davranışı sergiledikleri belirtilmiştir (Tanış ve Turunç, 2017, s.20).

Örgütlerin etkin ve verimli bir şekilde faaliyet göstermelerinde işlerin çok iyi planlanması ve koordine edilmesi gereklidir. Kanungo (1992, 
s.417), örgütte yapılması gereken işlerin, bunları açıklayan görev tanımlarının ve çalışanların rollerinin net bir şekilde belirlenmesinin gerekliliğini vurgulamıştır. Bunların sürekli değişmesi örgütte çalışanların iş üzerindeki kontrollerini kaybetmesine neden olabileceğinden, çalışanlar kendilerini yabancılaşmış hissedebilirler. İş ve görevler tekrar yapılandırıldığında, işte yaşanan tekdüzelik ortadan kalkabilir, iş genişletme ve iş zenginleştirme gibi uygulamalar ile çalışanların yabancılaşma duyguları azaltılabilir (Tutar, 2010, s.192).

Çalışanların örgütte yabancılaşmalarını Shepard (1971, s.387), üst seviyede makineleşmiş ve montaj bandında çalışanların, yaratıcılık becerisi gerektiren işlerde çalışan işçilere nazaran yabancılaşma duygusuna daha çok kapıldıklarını belirtmiştir. Tekdüze işleri yapan, belirli bir sürede belirli işi yapan, sıkı kontrol altında tutulan çalışanların farklılaştırılmış ve zenginleştirilmiş işleri yapan çalışanlara nazaran daha fazla yabancılaştıkları, yabancılaşan çalışanların (Banai ve Reisel, 2007, s.467) psikolojik olarak geri çekilme yaşayabilecekleri ve yaptıkları işe karşı daha düşük bağlllıklarının olabileceği belirtilmiştir (Parsak, 2010, s.16).

İşlerin farklılaştırılmasının ve çeşitlendirilmesinin diğer bir ifade ile zenginleştirilmesinin kimi çalışanlar üzerinde rahatsızlık yarattı̆̆, kimi çalışanlarda ise işe karşı olumlu tepkiler vermeleri nedeniyle daha çok motivasyon sağladığı, yüksek motivasyonlu çalışanların yabancılaşma hislerinin azaldığı belirlenmiştir (Shantz vd., 2015, s.382).

Tufail vd. (2017, s.225) alt düzey banka yöneticileri üzerinde yaptıkları araştırmada iş zenginleştirme uygulamalarının bu seviyedeki yöneticilerin örgütsel vatandaşlık davranışları üzerinde olumlu yönde etki yarattığı sonucuna ulaşmışlardır.

\section{Araştırmanın Amacı, Modeli ve Hipotezler}

Yapılan araştırmanın amacı, Örgütsel Vatandaşlık Davranışı (ÖVD), Örgütsel Yalnızlık (ÖY) ve İş Zenginleştirme (IZ) değişkenleri arasındaki ilişkiyi ve ÖVD ile ÖY değişkenleri arasındaki ilişkide İZ'nin aracılık rolünün olup olmadığını belirlemektir. Bu kapsamda yapılan araştırmada aşağıdaki soruların cevapları aranmıştır.

- ÖVD, IZZ üzerinde anlamlı olarak etkili midir?

- ÖVD, ÖY üzerinde anlamlı olarak etkili midir? 
- $\quad$ IZ, ÖY üzerinde anlamlı olarak etkili midir?

- ÖVD ile ÖY arasında anlamlı bir ilişki varsa bu ilişkide, İ'in aracılık rolü var mıdır?

Çalışmada kullanılacak ÖVD, ÖY ve İZ değişkenleri arasında ilişkileri gösterecek araştırma modeli Şekil-1'de gösterilmektedir. Araştırma modelinde ÖVD değişkenin ÖY değişkenin üzerinde, ÖVD değişkenin İZ değişkeni üzerinde ve İZ değişkeninin ÖY değişkeni üzerinde etkisi ile ÖVD değişkeni ile ÖY değişkeni arasındaki ilişkide İZ değişkeninin aracılık etkisinin bulunduğu gösterilmiştir.

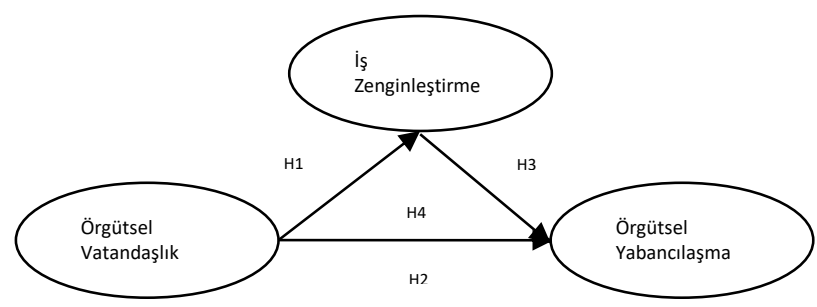

Şekil 1. Araştırma Modeli

Bu kapsamda Şekil-1'de sunulan modelde araştırılması planlanan değişkenler arasındaki ilişkiler ile ilgili olarak;

- $H_{1}$ :Çalışanlarm ÖVD düzeyi, ÖY algısın ters yönde ve anlamlı bir şekilde etkiler.

- $H_{2}$ :Çalışanları ÖVD düzeyi, İ'yi ayn yönde ve anlamlı bir şekilde etkiler.

- $\quad H_{3}:$ IZ, çalışanların ÖY algısın aynı yönde ve anlamlı bir şekilde etkiler.

- $H_{4}$ :Çalışanlarm ÖVD düzeyinin, çalışanlarm ÖY algısı üzerindeki etkisinde, IZ'nin aracıllk rolü vardır.

şeklinde dört adet hipotez kurulmuştur.

\section{Evren ve Örneklem}

Günümüzde ÖVD, ÖY ve İZ, hem kamu sektöründe hem de özel sektördeki birçok örgütte karşılaşılan durumları açıklayan kavramlardır. Ancak söz konusu kavramların en tipik örnekleri ağırlıklı olarak kamu sektöründe bulunmaktadır. Nitekim araştırma için ihtiyaç duyulan verilere ulaşmak kamu sektöründe hem daha kolay, hem de yeterli sayıda, eksiksiz ve doğru veriler 
elde etmek mümkün olmaktadır. Bu kapsamda yapılan çalışmada kullanılan veri seti MKE Pirinç Fabrikası Müdürlüğü çalsşanlarına uygulanan anket çalışması ile elde edilmiştir. MKE Pirinç Fabrikası Müdürlüğünde 460 kişi çalışmaktadır. Çalışmada kullanılan veri seti, yatay kesit verilerinden oluşmaktadır. Uygulamanın yapılacağı örneklem büyüklüğünün belirlenmesinde;

$$
n=\frac{N P Q Z^{2}}{(N-1) d^{2}+P Q Z^{2}}
$$

formülünden yararlanılmıştır (Orçanll, Oktay ve Birgören, 2018). Yapılan hesaplama sonucunda örneklem büyüklüğü 216 olarak bulunmuştur. Araştırmada kullanılmak üzere 300 adet soru formu hazırlanarak çalışanlara dağıtılmıştır. Anket uygulamasının ardından geri toplanan 230 formdan eksik doldurulmuş veya boş bırakılmış olanlar çıkarılmış, 217 soru formu değerlendirmeye alınmıştır.

\section{Veri Toplama Teknikleri}

Yapılan araştırmada veri toplama aracı olarak çalışmanın sonunda yer alan beşli Likert ölçeğine göre düzenlenen ve dört bölümden oluşan soru formu kullanılmıştır. Soru formunun birinci bölümünde demografik özelliklere ilişkin dokuz ifade, ikinci bölümünde İZ ile ilgili beş ifade, üçüncü bölümünde ÖY ile ilgili yirmi ifade ve son bölümünde ÖVD ile ilgili yirmi dört ifade olmak üzere toplamda elli sekiz ifade yer almaktadır.

Çalışmada kullanılan tek boyuttan oluşan İZ Ölçeği, Hackman, Oldham, Janson ve Purdy (1975) tarafından geliştirilmiş, Eren, Tokgöz ve Saylan (2014) tarafından Türkçe'ye çevrilerek geçerlilik ve güvenirlik testleri yapılmıştır. ÖY Ölçeği, Dean (1961) tarafından geliştirilmiş, Türkçe'ye Güğerçin ve Aksay (2017) tarafından uyarlanmış (1, 2, 3, 4 ve 6 ifadeler tersten kodlanmıştır), geçerlilik ve güvenirlik testleri yapılmıştır. ÖY Ölçeği, üç alt boyuttan oluşmaktadır. Bu boyutlar, sosyal yalıtılmışlık (9 adet ifade), güçsüzlük ( 6 adet ifade) ve kuralsızlık (5 adet ifade) alt boyutlarıdır. Beş boyuttan oluşan ÖVD Ölçeği, Organ (1988) tarafından geliştirilmiş, Orçanlı (2018) tarafından Türkçeye çevrilmiş geçerlilik ve güvenirlik testleri yapılmıştır. İfadeler "(1) Kesinlikle katılmıyorum, (2) Katılmıyorum, (3) Kararsizım, (4) Katılıyorum, (5) Kesinlikle katılıyorum" şeklinde kodlanmıştır. 
ÖVD Ölçeğinin Türkçe'de Geçerlilik ve Güvenirliği ile ÖY ve İ Ölçeklerinin Güvenirliklerinin Kontrolü

ÖVD Ölçeğinin Türkçe'de ilk defa kullanılmasından dolayı geçerliliği ve güvenirliğinin ölçülmesi gerekmektedir. Yapılan çalışmada üç adet konusunda uzman personel tarafindan Türkçe'ye madde madde tercüme edilmiş ve ölçülmesi istenen maddeler incelenmiştir. Ardından yapılan keşfedici faktör analizi ile yapısal geçerliliği kontrol edilmiştir. Yapılan denemeler kapsamında beş faktörlü olan ölçek tek faktörlü olarak kullanılmasının uygun olacağı değerlendirilmiştir. Ölçeğin tek faktörlü yapıya uygun olarak güvenirliliği test edilmiştir. Ölçek analizlerde (ÖV) kısaltmasıyla kullanılmıştır. ÖV Ölçeğinin Cronbach's Alpha katsayısının 0,83 ve KMO değerinin 0,78 olduğu belirlenmiştir.

Yapılan araştırmada kullanılan ölçeklerin güvenilirliği doğrulayıcı faktör analizi yöntemi ile kontrol edilmiş ve elde edilen modellerin AMOS programındaki gösterimi Şekil-2, Şekil-3 ve Şekil-4 ile uyum iyiliği ile ilgili sonuçlar ise Tablo-2'de sunulmuştur.

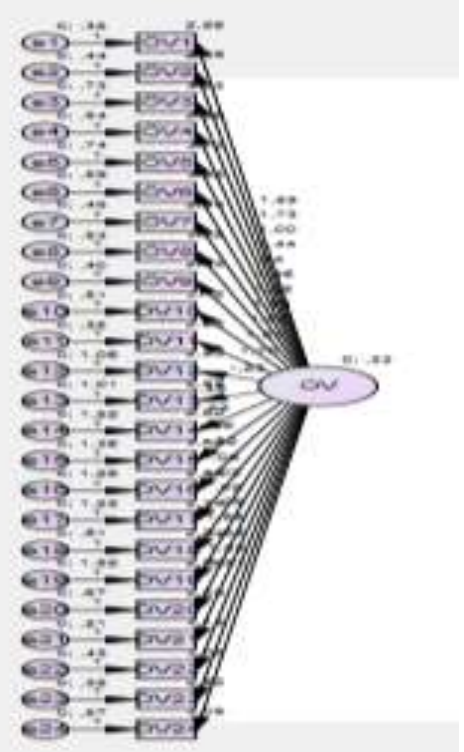

Şekil-2: ÖVD Ölçeği DFA Modeli

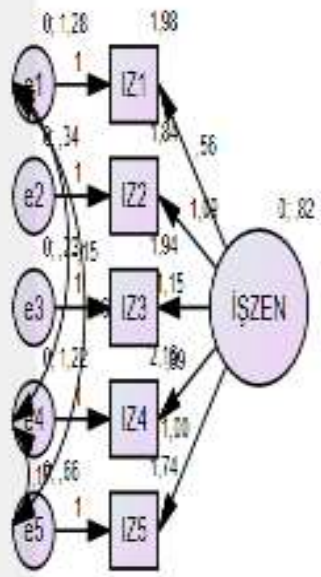

Şekil-3: İZ Ölçeği DFAModeli 


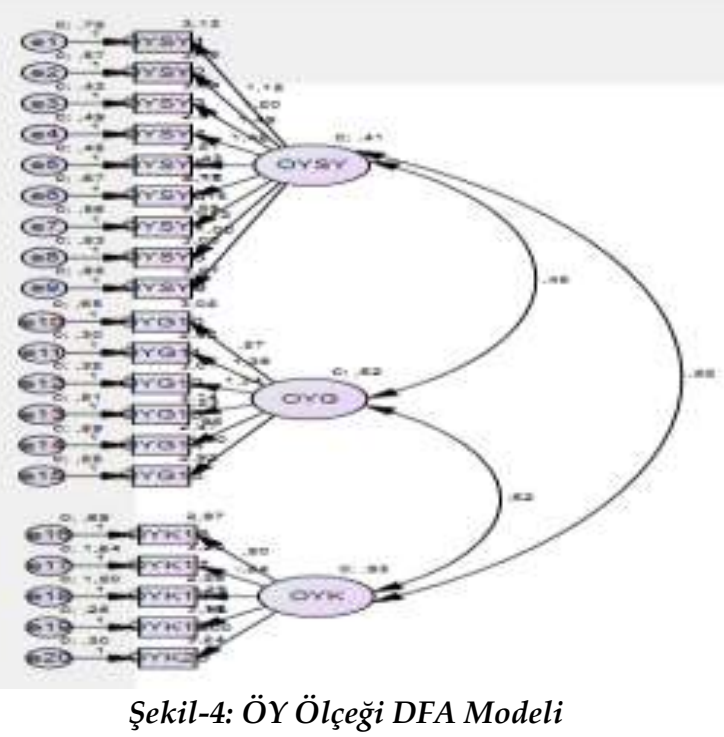

Tablo-1 incelendiğinde üç ölçeğin uyum iyiliği değerlerinin referans değerleri arasında olduğu ve iyi uyum gösterdikleri (MacCallum, Browne ve Sugawara, 1996; Meydan ve Şeşen, 2011) tespit edilmiştir. Bu kapsamda, ÖVD Ölçeğinin ve IZZ Ölçeğinin tek faktörlü bir yapıya ve ÖY Ölçeğinin ise üç faktörlü bir yapıya sahip olduğu ve söz konusu ölçekleri çalışmamızın yapıldığı örneklem grubunda rahatlıkla kullanılabileceği sonucuna ulaşılmıştır.

Tablo 1.Ölçeklerin Doğrulayıcı Faktör Analizi Sonuçları

\begin{tabular}{lllllll}
\hline Ölçek & $\chi \mathbf{2}$ & $\chi \mathbf{2} / \mathbf{s d}$ & RMSEA & CFI & GFI & NFI \\
\hline $\begin{array}{l}\text { ÖVD } \\
\text { Ölçeği }\end{array}$ & 2,96 & 1,47 & 0,047 & 0,891 & 0,945 & 0,981 \\
\hline ÖY Ölçeği & 5,17 & 2,085 & 0,068 & 0,904 & 0,912 & 0,945 \\
\hline İZ Ölçeği & 4,979 & 2,489 & 0,083 & 0,994 & 0,970 & 0,990 \\
\hline
\end{tabular}

Ayrıca SPSS 23 paket programı ile yapılan çalışmalar incelendiğinde İZ Ölçeğinin Cronbach's Alpha katsayısının 0,74 ve KMO (Kaiser-Meyer Olkin) değerinin 0,78; ÖY Ölçeğinin sosyal yalıtılmışlık, güçsüzlük ve kuralsızlık alt boyutlarının Cronbach's Alpha katsayılarının sırasıyla 0,$88 ; 0,86 ; 0,84$ ve KMO değerinin 0,84 olduğu belirlenmiştir. Ayrıca ÖVD ölçeğinin Cronbach's Alpha 
katsayısının 0,83 ve KMO değerinin 0,78 olduğu belirlenmştir. Kullanılan üç ölçeğin Cronbach's Alpha katsayıları Tablo-1'de sunulmuştur. Elde edilen değerler incelendiğinde kullanılan ölçeklerin iç tutarlılıklarının oldukça güvenilir olduğu, ayrıca ölçekte yer alan ifadelerin aynı boyutun öğelerini ölçen ifadeler olduğu görülmektedir (Özdamar, 2013).

Yapılan araştırmada ilişkisel araştırma deseni ve analizde Yapısal Eşitlik Modellemesi yöntemi kullanılmıştır.

\section{Bulgular}

Anket uygulamasına katılanların anket sorularına verdikleri cevaplardan elde edilen frekanslar ve yüzdelik değerlerin olduğu betimsel istatistikler Tablo-2' de sunulmuştur.

Tablo 2. Betimleyici Ístatistikler $(\mathrm{N}=217)$

\begin{tabular}{|c|c|c|c|}
\hline Değişkenler & Frekans & Değişkenler & Frekans \\
\hline \multirow{2}{*}{ Cinsiyet } & Erkek & \multirow{2}{*}{ Medeni Durum } & Evli \\
\hline & Kadın & & Bekâr : 59 \\
\hline \multirow{5}{*}{$\begin{array}{l}\text { İşletmedeki } \\
\text { Pozisyonu }\end{array}$} & \multirow{5}{*}{$\begin{array}{l}\text { Yönetici } \\
\text { Çalışan }\end{array}$} & \multirow{5}{*}{ Yaş } & 24 ve altı : 12 \\
\hline & & & $25-34 \quad: 69$ \\
\hline & & & $35-44$ \\
\hline & & & $45-54 \quad: \quad 45$ \\
\hline & & & 55 ve üstü : 3 \\
\hline \multirow{6}{*}{$\begin{array}{l}\text { Öğrenim } \\
\text { Durumu }\end{array}$} & \multirow{6}{*}{$\begin{array}{lll}\text { O/Y değil } & : & 0 \\
\text { Okuryazar: } & 1 \\
\text { Ilk } & : & 14 \\
\text { Orta } & : & 47 \\
\text { Lise } & : & 124 \\
\text { Üniversite: } & 31 \\
\end{array}$} & \multirow{6}{*}{ Yaşam Yeri } & \\
\hline & & & Kirikkale \\
\hline & & & Merkez : 185 \\
\hline & & & Kırıkkale \\
\hline & & & Kirsalı $\quad: 12$ \\
\hline & & & Başka şehir: 20 \\
\hline \multirow{6}{*}{ Aile Fert Sayısı } & & \multirow{6}{*}{$\begin{array}{l}\text { Aile Toplam } \\
\text { Gelir }\end{array}$} & 1500 ve altı : 2 \\
\hline & $\begin{array}{l}: 101 \\
. \quad 90\end{array}$ & & $1501-2000: 34$ \\
\hline & $\begin{array}{l}: 90 \\
. \quad 14\end{array}$ & & $2001-2500: 45$ \\
\hline & $\begin{array}{l}: \quad 14 \\
: \quad 1\end{array}$ & & $2501-3000: 45$ \\
\hline & $7-8$ & & $3001-3500: 64$ \\
\hline & 9 ve üstu : 1 & & 3501 ve üstü: 27 \\
\hline \multirow{3}{*}{$\begin{array}{l}\text { Sosyal Güvenlik } \\
\text { Durumu }\end{array}$} & Memur & & \\
\hline & SSK & & \\
\hline & Diğer & & \\
\hline
\end{tabular}

YEM yönteminde sağlanması gereken varsayımların kontrol edilmesinden sonra ÖY, İZ ve ÖVD değişkenleri arasında ilişki olup olmadığının 
belirlenmesi için elde edilen verilerin ortalama, standart sapma ve korelasyon değerleri incelenmiştir. Analiz sonucunda elde edilen istatistiki değerler Tablo-4'de sunulmuştur.

Tablo 3. Değişkenlerin Ortalama ve Standart Sapma Değerleri ile İlişki Katsayıları

\begin{tabular}{|c|c|c|c|c|c|c|}
\hline & & ORT & SS & ÖVD & ÖY & İZ \\
\hline \multirow{2}{*}{ ÖVD } & $\underline{r}$ & \multirow{2}{*}{$-2,86$} & \multirow{2}{*}{0,56} & \multirow[t]{2}{*}{1} & $-0,76$ & 0,657 \\
\hline & $p$ & & & & 0,00 & 0,00 \\
\hline \multirow{2}{*}{ ÖY } & $r$ & \multirow{2}{*}{$-2,99$} & \multirow{2}{*}{0,72} & $\underline{-0,76}$ & 1 & 0,833 \\
\hline & $p$ & & & 0,00 & & 0,00 \\
\hline \multirow{2}{*}{ İZ } & $r$ & \multirow{2}{*}{$-2,91$} & \multirow{2}{*}{0,93} & 0,657 & 0,833 & 1 \\
\hline & $p$ & & & 0,00 & 0,00 & \\
\hline
\end{tabular}

Tablo-3'deki değişkenlerin arasındaki korelasyon değerleri incelendiğinde hepsinin anlamlı ve güçlü olduğu görülmüştür. Evans (1996)'a göre; korelasyon değerleri "0.00-0.19: Çok zayıf, 0.20-0.39: Zayıf, 0.40-0.59: Orta, 0.60-0.79: Güçlü ve 0.80-1.00: Çok güçlü" ilişkiyi göstermektedir. Bu çalışmada bu değerler esas alınmıştır. Bu kapsamda;

- OOVD ile ÖY değişkenleri arasında ters yönlü ve güçlü bir ilişkinin $(r=0,76, p(0,000)<0,05)\left(H_{1}\right.$ hipotezi kabul $)$,

- ÖVD ile IZ değişkenleri arasında aynı yönlü ve güçlü bir ilişkinin $(r=0,657, p(0,00)<0,05)),\left(H_{2}\right.$ hipotezi kabul $)$,

- IZ ile ÖY değişkenleri arasında aynı yönlü ve çok güçlü bir ilişkinin $(r=0,833, p(0,00)<0,05))\left(H_{3}\right.$ hipotezi kabul $)$ olduğu tespit edilmiştir.

Ulaşılan ilişki durumu, incelenen üç değişken arasındaki ilişkinin teorik bölümde anlatılan ilişkiler ile benzer ve destekler nitelikte olduğu görülmüştür. Dolayısıyla değişkenler ile kurulması planlanan modelin ilişki ölçüleri ile literatür kısmında verilen bilgilerin birbirini destekler nitelikte olduğu görülmektedir. Ancak kesin yargıya YEM yöntemi ile ilgili olarak elde edilecek uyum değerlerine bakılarak karar verilecektir.

Kurulan modeli test etmeden önce ilk olarak ölçme modelinin test edilmesi amaçlanmıştır. Ancak YEM yönteminde ölçme modelinin oluşturulup test edilmesi şartı yoktur.

Çalışmada analizlerin yapılmasında en yüksek olabilirlik (maximum likelihood) kestirim yöntemi kullanılmıştır. Bu kapsamda AMOS paket programında değişkenler ile ilgili kurulan ölçme modelinin program çıktısı ve değerleri Şekil-5'te sunulmuştur. 


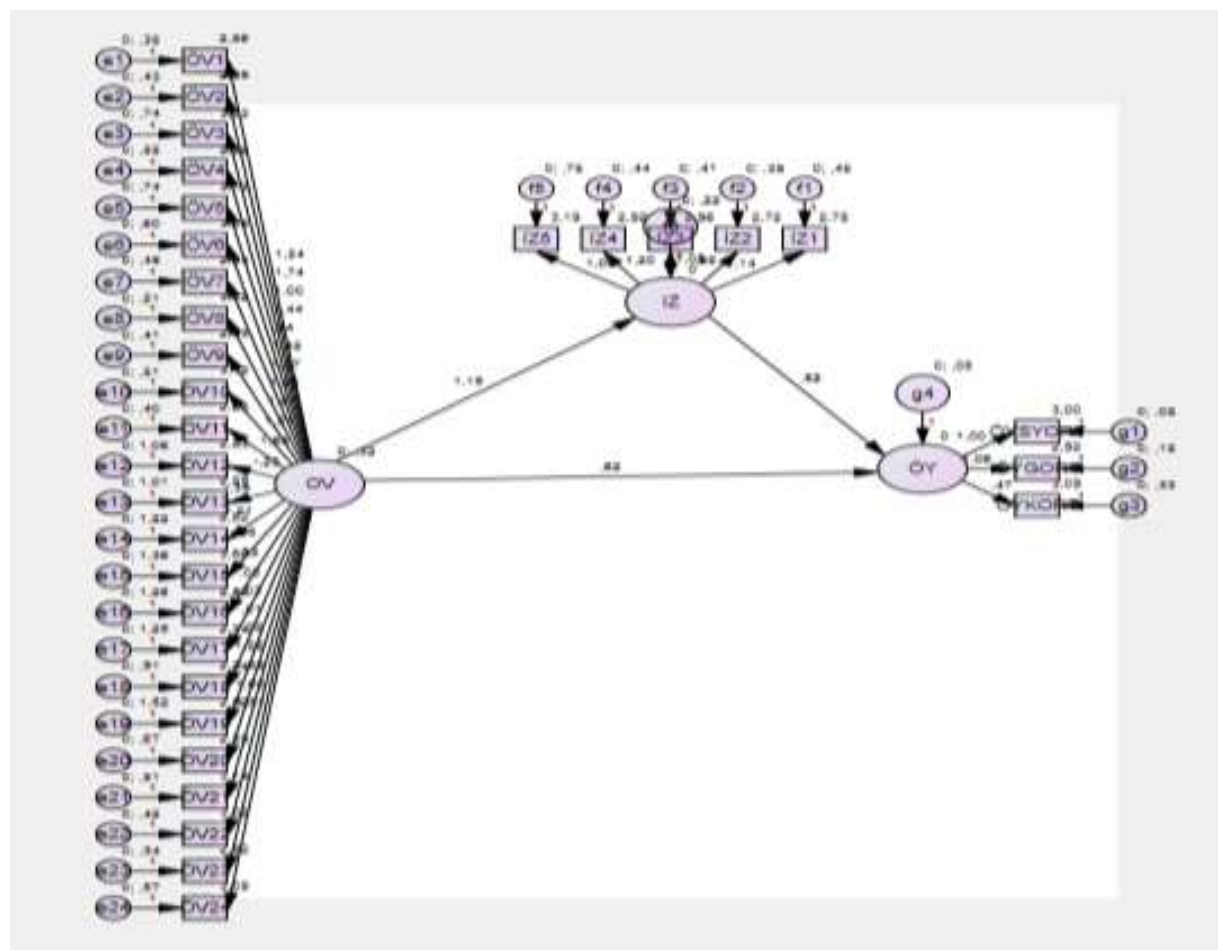

\section{Şekil 5. Ölçme Modelinin Program Çıktısı ve Değerleri}

Ölçekler ile ilgili kullanılan örnekleme ait ölçme modelinin istatistiki ve uyum iyiliği değerleri ile bunlara ait Kabul edilebilir referans aralık değerleri Tablo-4'te sunulmuştur.

Tablo-4: Ölçme Modelinin İstatistiki ve Uyum İyiliği Değerleri

\begin{tabular}{|c|c|c|c|c|c|c|c|c|c|}
\hline SRMR & GFI & $A G F I$ & CFI & NFI & $\begin{array}{l}\text { NNFI } \\
\text { (TLI) }\end{array}$ & RMSEA & $\begin{array}{l}\text { CMIN } \\
/ \\
S D \\
\end{array}$ & $X^{2}$ & $p$ \\
\hline 0,09 & 0,91 & 0,84 & 0,95 & 0,92 & 0,91 & 0,08 & 3,16 & 1,84 & $\begin{array}{l}0,0 \\
0 \\
\end{array}$ \\
\hline $\begin{array}{l}0,05 \leq \\
S R M R \leq \\
0,1\end{array}$ & $\begin{array}{l}0,9 \leq \\
G F I \leq \\
0,95\end{array}$ & $\begin{array}{l}0,85 \leq \\
A G F I \leq \\
0,9\end{array}$ & $\begin{array}{l}0,95 \leq \\
C F I \leq \\
0,97\end{array}$ & $\begin{array}{l}0,90 \leq \\
N F I \leq \\
0,95\end{array}$ & $\begin{array}{l}0,95 \leq \\
N N F I \leq \\
0,97\end{array}$ & $\begin{array}{l}0,05 \leq \\
R M S E A \leq \\
0,07\end{array}$ & $\begin{array}{l}2 \leq \\
C M I N / \\
S D \leq 3\end{array}$ & $\begin{array}{l}2 S D \\
\leq \\
X^{2} \leq \\
3 S D\end{array}$ & $\begin{array}{l}0,0 \\
0\end{array}$ \\
\hline
\end{tabular}

Şimşek, Ö.F. (2007). Yapısal Eşitlik Modellemesine Giriş: Temel Illkeler ve LISREL Uygulamaları, Ekinoks Yayınları, Ankara. 
Ölçme modelinin uyum değerleri incelendiğinde bütün değerlerin ideal veya kabul edilebilir sınırlar içinde olduğu tespit edilmiştir. Dolayısıyla anket sonucunda elde edilen verilerin çalışmamızda uygun olarak kullanılabileceği değerlendirilmiştir.

\section{İZ'nin Aracılık Etkisinin Olmadı̆̆ı, ÖVD ile ÖY Değişkenleri Arasındaki İlişkinin YEM Yöntemi ile Test Edilmesi (Model-1)}

İlk olarak aracı değişkenin modelde olmadığı, ÖVD ile ÖY değişkenleri arasında kurulan yolun testi yapılmıştır. Bu kapsamda, test sonucunda Şekil8'de yer alan modelin elde edilen istatistiki ve uyum değerleri Tablo-6'da sunulmuştur.

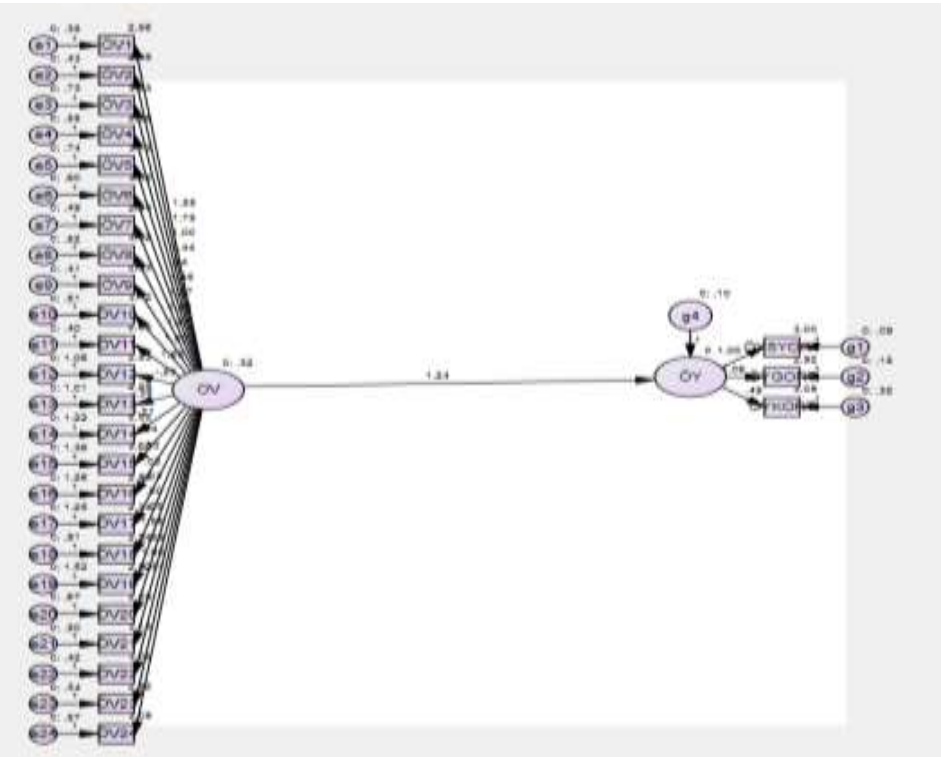

Şekil 6. Model-1'in YEM Yöntemiyle İncelenmesi

Tablo 5. Model-1'in İstatistiki ve Uyum İyiliği Değerleri

\begin{tabular}{llllllllll}
\hline SRMR & GFI & AGFI & CFI & NFI & $\begin{array}{l}\text { NNFI } \\
\text { (TLI) }\end{array}$ & RMSEA & $\begin{array}{l}\text { CMIN/ } \\
\text { SD }\end{array}$ & $X^{2}$ & $p$ \\
\hline 0,09 & 0,91 & 0,84 & 0,95 & 0,92 & 0,91 & 0,066 & 3,16 & 1,84 & 0,00 \\
\hline
\end{tabular}


Tablo-5'de yer alan değerler incelendiğinde bütün uyum değerlerinin belirlenen referans değerlerinin arasında olduğu ve söz konusu bütün uyum iyiliği değerlerinin anlamlı olduğu görülmüştür. Ayrıca ÖVD ile ÖY değişkenleri arasında çizilen yola ait standardize edilmiş $\beta$ katsayısı, standart hatası ile anlamlılık düzeyi değerleri Tablo-6'da sunulmuştur.

Tablo 6. Model-1'in Standardize Edilmiş $\beta$ Katsayısı, Standart Hatası ile Anlamlılık Düzeyi Değerleri

\begin{tabular}{llll}
\hline Yol & $\begin{array}{l}\text { Standardize } \\
\beta \text { Katsayısı }\end{array}$ & Standart Hata & $\begin{array}{l}\text { Anlamlılık } \\
\text { Düzeyi }\end{array}$ \\
\hline ÖV $\rightarrow$ ÖY & $-0,76$ & 1,021 & 0,011 \\
\hline
\end{tabular}

Tablo-6'da yer alan değerler incelendiğinde ÖV ile ÖY değişkenleri çizilen yolun anlamlı olduğu $(p(0,011)<0,05)$ tespit edilmiştir.

İZ'nin Aracılık Etkisinin Olduğu, ÖVD ile ÖY Değişkenleri Arasındaki İlişkinin YEM Yöntemi ile Test Edilmesi (Model-2)

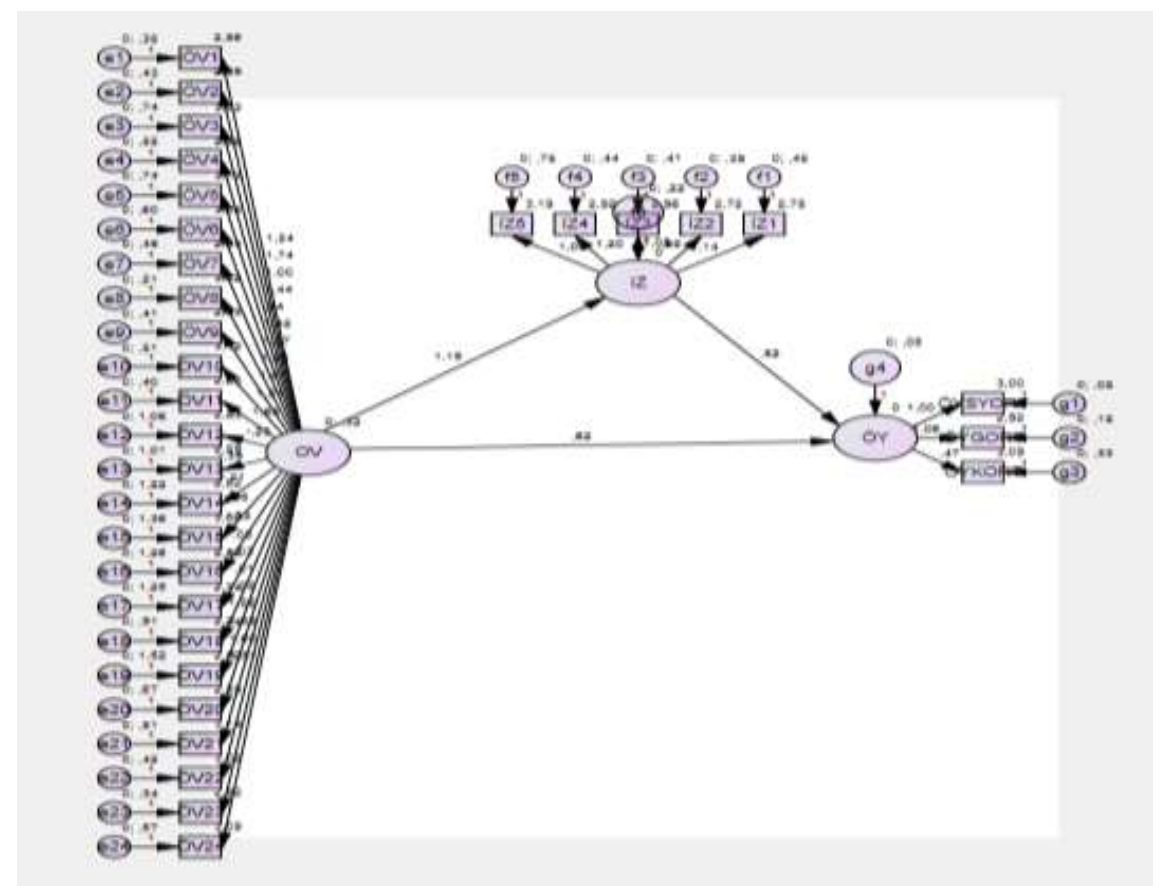

Şekil 7. Model-2'nin YEM Yöntemiyle İncelenmesi 
Model-1 test edildikten sonra aracı değişkenin modelde olduğu, ÖVD ile ÖY değişkenleri arasında kurulan yolun testi yapılmıştır. Yapılan test sonucunda Şekil 9'da sunulan modele yönelik elde edilen istatistiki değerler Tablo 7'de sunulmuştur.

Tablo 7. Model-2'nin İstatistiki ve Uyum İyiliği Değerleri

\begin{tabular}{llllllllll}
\hline SRMR & GFI & AGFI & CFI & NFI & $\begin{array}{l}\text { NNFI } \\
\text { (TLI) }\end{array}$ & RMSEA & $\begin{array}{l}\text { CMIN/ } \\
\text { SD }\end{array}$ & $X^{2}$ & $p$ \\
\hline 0,087 & 0,89 & 0,94 & 0,925 & 0,912 & 0,944 & 0,08 & 4,18 & 2,84 & 0,012 \\
\hline
\end{tabular}

Tablo-7'de yer alan değerler incelendiğinde bütün uyum değerlerinin belirlenen referans değerlerinin arasında olduğu ve anlamlı olduğu görülmüştür.

ÖVD, ÖY ve IZZ değişkenleri arasındaki çizilen yollara ait standardize edilmiş $\beta$ katsayıları, standart hataları ile anlamlılık düzeyleri Tablo-9'da yer almaktadir.

Tablo 8. Model-2'nin Standardize Edilmiş $\beta$ Katsayılan, Standart Hatalan ile Anlamlilık Düzeyleri

\begin{tabular}{|c|c|c|c|}
\hline Yol & $\begin{array}{l}\text { Standardize } \\
\beta \text { Katsayısı }\end{array}$ & Standart Hata & $\begin{array}{l}\text { Anlamlılık } \\
\text { Düzeyi }\end{array}$ \\
\hline ÖV $\rightarrow$ ÖY & $-0,62$ & 1,007 & 0,023 \\
\hline İZ $\rightarrow$ ÖY & 0,52 & 0,7 & 0,017 \\
\hline ÖV $\rightarrow$ İZ & 0,49 & 0,715 & 0,015 \\
\hline
\end{tabular}

Tablo-8'de yer alan değerler incelendiğinde ÖV ile ÖY değişkenleri çizilen yolun anlamlı olduğu $(p(0,023)<0,05)$ ancak $\beta$ katsayılarında (model1:-0,76 ile model-1:-0,62) ve uyum değerlerinden RMSEA uyum iyiliği değerinde (model-1 RMSE $A=0,066$ ve model-2 RMSE $A=0,08$ ) ise düşme veya kötüleşme olduğu tespit edilmiştir. Bu durum İZ'nin; ÖVD ile ÖY değişkenleri arasında kısmi aracılık rolüne sahip olduğunu göstermektedir. ÖVD ile ÖY değişkenleri arasında tespit edilen kısmi aracılık etkisinin anlamlı olup olmadığını belirlemek üzere Sobel Testi yapılmıştır. Sobel Testinin temelinde, modelde bulunan değişkenlere ait regresyon ağırlıkları ile değişkenler arasındaki ilişkilere ait standart hataları göz önüne alarak regresyon katsayısındaki değişimin anlamlılığının test edilmesi yer alır (Preacher ve Hayes, 2004). Yapılan test sonucunda azalış anlamlı değil ise değişkenler arasında kısmi araclıktan söz edilemez. 
Yapılan Sobel Testi $(z=3,054 ; p<0,05)$ sonucunda ÖVD ile ÖY değişkenleri arasında ilişki anlamlı bulunmuş ve dolayısıyla İZ'nin belirtilen değişkenler arasında kısmi aracılık etkisinin olduğu ( $H_{4}$ hipotezi kabul) belirlenmiştir.

\section{Sonuç}

Yapılan bu çalışmada, ÖVD ile ÖY değişkenleri arasındaki ilişkide İZ'nin aracılık etkisinin olup olmadığı araştırılmıştır. Çalışmanın ilk bölümünde ÖVD, IZ ve ÖY değişkenleri ile ilgili kavramsal olarak incelenmiştir. Müteakiben ÖVD, ÖY ve İZ değişkenlerinin ölçülebilmesi amacıyla kullanılan ölçekler farklı örneklemlere uygulanmasından dolayı geçerlilikleri ve güvenirlikleri kontrol edilmiş ve bu çalışmada kullanılabileceği belirlenmiştir. Ancak ölçeklerde ÖVD ölçeği yabancı literatürde beş boyutlu olarak kullanılırken yapılan çalışmada faktör analizi sonucunda tek boyutlu olarak kullanılabileceği görülmüştür. Bu analizlerin ardından ÖV ile ÖY değişkenleri arasındaki ilişkide İZ'nin aracılık etkisi YEM yöntemi ile test edilmiştir. Uygulamanın sonunda IZ, ÖVD ile ÖY değişkenleri arasında korelasyon analizi sonucunda anlamlı ilişkilerin olduğu ve kurulan hipotezlerden ilk üçünün sağlandığı tespit edilmiştir. Ayrıca dördüncü hipotez ile yapılan analizler sonucu İZ'nin; ÖVD ile ÖY değişkenleri arasında kısmi aracılık rolüne sahip olduğu tespit edilmiştir. Ancak kısmi aracılık rolüne sahip olunan değişkenler arasındaki yollarda genel olarak standardize edilmiş beta katsayılarının değerlerinde bir düşüş yaşandığı tespit edilmiştir. Kısmi aracılık etkisinin tespit edilmesi müteakip atılması gereken bir diğer adım ise, Sobel Testi ile kısmi aracılık etkisinde meydana gelen düşüşün anlamlı olup olmadığının belirlenmesidir. Yapılan Sobel Testi sonucunda ÖV ile ÖY değişkenleri arasındaki ilişkinin anlamlı olduğu ve dolayısıyla İZ'nin belirtilen değişkenler arasında kısmi aracılık etkisinin bulunduğu tespit edilmiştir.

Yapılan analizler sonucunda elde edilen verilerin literatürde yer alan çalışmalarla desteklendiği görülmüştür. Averbek (2016, 73) tarafindan yapılan çalışmada öğretmenlerin ÖVD'nın ÖY üzerinde olumlu yönde etkisi olduğu, benzer şekilde Keser ve Karaduman $(2014,178)$ ÖVD ile ÖY arasında olumsuz yönlü ilişki olduğu sonucuna ulaşmışladır. Turhan $(2019,192)$ yaptığı araştırmada ÖVD ile ÖY arasında olumsuz ilişkiye yönelik benzer sonuçlara ulaşmıştır. Çalışanların örgütsel vatandaşlık davranışlarının 
geliştirilmesinde iş zenginleştirmenin önemli etkisinin olduğu (Bolat ve Bolat, 2008; 75) ve örgütlerde çalışanların iş genişletme ve iş zenginleştirme yöntemleri ile yabancılaşmalarının önlenmesine yönelik tedbirler alınabileceği belirtilmiştir (Parsak, 2010; 77).

Yapılan çalışmada üç değişken kullanılmıştır. Ancak söz konusu çalışmada kurulan modele başka değişkenlerde eklenebilir ve model geliştirilebilir. Yapılan literatür çalışması sonunda ÖY değişkenini farklı şekillerde etkileyen değişkenlerde bulunduğu görülmüştür. Bu çalışma değişkenler arasında aracılık testlerinin hiyerarşik regresyon yöntemi haricinde YEM yöntemi ile de yapılabileceği bu alanda yeni çalışmaya başlayanlar için bir rehber olacağı değerlendirilmektedir.

Kuramsal ve pratik sahaya yönelik çıkarımlarının yanında çalışma bir takım sınırlılıklarda taşımaktadır. Öncelikle ampirik araştırma kamu sektöründe uygulanmış olup özel sektörde yapılacak araştırmalarda farklı sonuçların elde edilmesi olasıdır. Dolayısıyla aynı modelin özel sektörden toplanacak veriler ile tekrar yapılmasının ve bu çalışma ile karşılaştırılmasının uygun olacağı değerlendirilmektedir. 


\title{
EXTENDED ABSTRACT
}

\section{The Effect of Job Enrichment as a Mediator Role on Relationship between Organizational Citizenship and Organizational Alienation}

\author{
Kemal Eroğluer \\ Nation Defence University
}

In the literature, it is known that organizational citizenship (OC) and job enrichment (JE) have an effect on organizational alienation (OA). Ceteris paribus, organizational citizenship is inversely proportion to organizational alienation and job enrichment is proportion to organizational alienation. In the literature, many researchers have investigated relationship between organizational alienation, organizational citizenship and job enrichment, however, it hasn't been investigated whether job enrichment has any mediating effect in the relationship between organizational citizenship and organizational alienation or not. In this context, the aim of this study is to find the mediating role of job enrichment on relation between organizational alienation and organizational citizenship.

OC is defined as dedication of employees, the units or departments to materialize objectives of an organization beyond the role requirements set in the organization (Somech ve Drach-Zahavy, 2000; Feather ve Rauther, 2004). Extra role behavior in OC has three features. First, the behavior is voluntary rather than the a requirement of the job. Second, realization of the behavior is not easy moreover, it is directed towards and it is beneficial for the organization. Finally third one is that the OC is multidimensional. The studies which focuses on OC, describe five dimensions. These dimensions are as altruism, task awareness, gentlemen, kindness and virtue.

Froom (1991, s.125) described the concept of alienation as a disease, and defined the individual as separating himself from his environment and other individuals, getting lonely and feeling alien. The main reason of alienation in organizations is stated by Örnek and Aydın (2008, p.207) that the working environment does not satisfy the employee and stress caused by this dissatisfaction. In his study on alienation in 1959, Seeman examined alienation in 
five different dimensions as "weakness", "meaninglessness", "normality", "distance from the environment" and "self-alienation".

Job enrichment (JE) are positive improvements made to increase the re sponsibilities and success of employees in the works related to organizational activities. Job enrichment is that the job offers more responsibility, recognition and opportunities for growth and progress (Daft, 2015, p.516).

In this research, a questionnaire form which is located at the end of the study is used as a data collection tool that consists from four parts and based on the Likert scale. In the first part of the questionnaire, there are nine expressions related to demographic characteristics, five expressions about JE in the second section, twenty expressions about OA in the third section and twenty four expressions about OC in the last section.

The JE Scale, which consists of one dimension, was developed by Hackman, Oldham, Janson and Purdy (1975), and was translated into Turkish by Eren, Tokgöz and Saylan (2014) and validity and reliability tests were performed. The OA Scale was developed by Dean (1961), adapted to Turkish by Güğerçin and Aksay (2017) (1, 2, 3, 4 and 6 expressions were coded in reverse), and validity and reliability tests were performed. The OA Scale consists of three sub-dimensions. These dimensions are social isolation ( 9 expressions), weakness (6 expressions) and uncertainty (5 expressions) subscales. The OC Scale, which consists of five dimensions, was developed by Organ (1988) and translated into Turkish by Orçanl (2018), validity and reliability tests were performed.

The hypotheses of the study are as follows:

- H1: Employee's OC level has an opposite and significant impact on OA.

- H2: Employee's OC level has a same way and significant impact on JE.

- H3: JE has a same way and significant impact on employee's OA perception.

- H4 JE has a mediating role on employee's OC level's impact on OA perception

After checking the assumptions that should be provided in the SEM method, the average, standard deviation and correlation values of the obtained data were examined to determine whether there is a relationship between the variables of OA, JE and OC. There is an inverse and strong 
relationship between OC and OA variables $(\mathrm{r}=-0,76, \mathrm{p}(0,000)<0.05$ (H_1 hypothesis accepted). A strong correlation between ÖVD and JE variables $(\mathrm{r}=$ $0.657, \mathrm{p}(0.00)<0.05)$,) (accept the H_2hypothesis), It was determined that there is a very strong correlation between JE and OA variables $(\mathrm{r}=0.833, \mathrm{p}(0.00)$ $<0.05)$ (H_3 hypothesis accepted). The relationship status reached and the relationship between the three variables examined were similar and supportive to the relations described in the theoretical section

As a result of the correlation analysis between JE, OC and OA variables at the end of the application, it was determined that there were significant relationships and the first three of the established hypotheses were provided. In addition, as a result of the analyzes made with the fourth hypothesis; It has been determined that it has a partial mediation role between OC and OA variables. However, it has been found that there is a decrease in the values of the standardized beta coefficients in the roads between the variables that have a partial mediation role. Another step to be taken after determining the partial mediation effect is to determine whether the decrease in the partial mediation effect is significant with the Sobel Test. As a result of the Sobel Test $(z=3.054$; $\mathrm{p}<0.05$ ), it was determined that the relationship between the variables of OC and OA is significant and therefore JE has a partial mediating effect (H_4 hypothesis acceptance) between the specified variables.

It has been stated that job enrichment has an important effect in the development of organizational citizenship behaviors of employees (Bolat ve Bolat, 2008, p.75), and measures can be taken to prevent alienation of employees by job expansion and job enrichment (Parsak, 2010, s.77). The results obtained after the analysis have shown that the work enrichment has a partial mediating role in the relationship between organizational citizenship and organizational alienation.

\section{Kaynakça / References}

Allison, B. J., Voss, R. S. ve Dryer, S. (2001). Student classroom and career success: The role of organizational citizenship behavior. Journal of Education for Business, 282-288..

Alpar R. (2012). Uygulamalı istatistik ve geçerlilik-güvenirlik. Ankara: Detay Yayıncilik. 
Altay, H. ve Dedeoğlu. B.B. (2016). Mediating role of organızational cynicism and work alienation in the relationship of ethical leadership and organizational citizenship behavior: Antakya tourism sector employees sample. BJSS Balkan Journal of Social Sciences, International Congress of Management Economy and Policy. 458-474.

Aslan, Ş. (2008). Örgütsel vatandaşlık davranışı ile örgütsel bağlılık ve mesleğe bağlılık arasındaki ilişkilerin araştırılması. Celal Bayar Üniversitesi İ̈F Yönetim ve Ekonomi, 15(2), 163-178.

Ateş, M.F., Turgut, H. ve Tokmak, İ. (2017). İşyeri güvenlik ikliminin iç girişimcilik üzerine etkisinde psikolojik sermayenin düzenleyici rolü. Uluslararası İktisadi ve İdari İncelemeler Dergisi, 16. UIK Özel Sayısı, 665-680.

Averbek, E. (2016). Illkokullarda görevli öğretmenlerin örgütsel yabancilaşma ile örgütsel vatandaşlık davranışları arasındaki ilişki. Yüksek Lisans Tezi, Dicle Üniversitesi Eğitim Bilimleri Enstitüsü. Diyarbakır.

Banai, M. ve Reisel, W. D. (2007). the influence of supportive leadership and job characteristics on work alienation: A six - country investigation, Journal of World Business, 42, 463-476.

Barksdale, K. ve Werner, J.M. (2001). Managerial ratings of in-role behaviors, organizational citizenship behaviors and overall performance: Testing different models of their relationship. Journal of Business Research, 51,145-155.

Bateman T.S., Organ Dennis, W. (1983). Job satisfaction and the good soldier: The relationship between affect and employee citizenship. Academy of Management Journal, 587-595.

Bayram, N.(2010). Yapısal eşitlik modellemesine giriş AMOS uygulamaları. Bursa: Ezgi Kitabevi.

Bolat, O. İ. ve Bolat, T. (2008). Otel işletmelerinde örgütsel bağlllık ve örgütsel vatandaşlık davranışı ilişkisi. Balıesir Üniversitesi SBE Dergisi, 11(19), 7594.

Bolat, T. (2008). Dönüşümcü liderlik, personeli güçlendirme ve örgütsel vatandaşlık davranışı ilişkisi. Ankara: Detay Yayıncılık.

Choudhary, S. (2016). Job enrichment: A tool for employee motivation. International Journal of Applied Research, 2(5), 1020-1024.

Çetin, Ö. (2014). Örgütsel vatandaşlık davranışı. Nobel Yayıncılık: Ankara.

Daft, R.L. (2015). Örgüt kuramları ve tasarımını anlamak. (çev. Ö N. Timurcanday Özmen), (10. Basımdan çeviri). Ankara: Nobel Yayıncllık. 
Dağll, A. ve Averbek, E. (2017). The relationship between the organizational alienation and the organizational citizenship behaviors of primary school teachers, Universal Journal of Educational Research, 5(10), 1707-1717.

Dean, D.G. (1961). Alienation: Its meaning and measurement. American Sociological Review, 5(26), 753-758.

Demirel, G. ve Ünal, A. (2011). Meslek yüksekokullarında turizm eğitimi alan öğrencileri örgütsel yabancılaşma eğilimlerini belirlemeye yönelik bir araştırma: Pınarhisar MYO örneği. II. Uluslararası VI. Ulusal Meslek Yüksekokulları Sempozyumu.

Dost, M.K.B. ve Khan, H.J. (2012). Job enrichment causes high level of employee commitment during the performance of their duties: A behavioral study. Arabian Journal of Business and Management Review (Oman Chapter), 1(10), 95 .

Elma, C. (2003). İlköğretim okulu öğretmenlerinin işe yabancılaşması:Ankara İli Örneği. Yayımlanmamış Doktora Tezi, Ankara Üniversitesi Eğitim Bilimleri Enstitüsü, Ankara.

Eren, M.Ş., Tokgöz, E. ve Saylan, O. (2014). Stratejik insan kaynakları yönetiminin işgören katılımı üzerindeki etkisi: İş zenginleştirme ve güçlendirmenin düzenleyici etkisi. Süleyman Demirel Üni. İ̈BF Dergisi, 19(2), 89-106.

Evans, J.D. (1996). Straightforward statistics for the behavioral sciences. Pacific Grove, CA: Brooks/Cole Publishing.

Feather, N.T. ve Rauter, K.A. (2004). Organizational citizenship behaviours in relation to job status, job insecurity, organizational commitment and identification: Job satisfaction and work values. Journal of Occupational and Organizational Psychology, 77, 81-94.

Fettahlığlu, T. (2006). Örgütlerde yabancılaşmanın yönetimi: kahramanmaraş özel işletme ve kamu kuruluşlarında karşılaştırmalı bir araştırma. Yayımlanmamış Yüksek Lisans Tezi, Kahramanmaraş Sütçü İmam Üniversitesi Sosyal Bilimler Üniversitesi, Kahramanmaraş.

Fromm, E. (1991). Freud düşüncesinin büyüklü̈̆̈̈̈ ve sinırlılı̆̆ı. (Çev. A.Arıtan), (3. Bsm), Arıtan Yayınevi: İstanbul.

George, J.M. ve Brief, A.P. (1992). Feeling good-doing good: A conceptual analysis of the mood at work-organizational spontaneity relationship. Psychological Bulletin, 112, 310-339. 
Güğercin, U. ve Aksay, B. (2017). Dean'ın yabancilaşma ölçeğinin Türkçe Uyarlaması: Geçerlilik ve güvenirlik analizi. Uluslararası Yönetim Íktisat ve İşletme Dergisi, 13(1), 137-154.

Hackman, R.J., Oldman, G., Janson, R. ve Purdy, K. (1975). A new strategy for job enrichment. California Management Review, 17(4), 57-71.

İşbaşı, J. (2000). Çalışanlarm yöneticilere duydukları güvenin ve örgütsel adalete ilişkin algılamalarının örgütsel vatandaşlık davranışının oluşumundaki rolü: Bir turizm örgütünde uygulama. Yayımlanmamış Yüksek Lisans Tezi. Akdeniz Üniversitesi SBE. Antalya.

Kanungo, R.N. (1992), Alienation and empowerment: Some ethical imperatives in business. Journal of Business Ethics, 5(6), 413-422.

Karaaslan, A., Özler, D.E. ve Kulaklığlu, S. (2009). Örgütsel vatandaşlik davranişi ve bilgi paylaşimini arasindaki ilişkiye yönelik bir araştirma. Afyon Kocatepe Üniversitesi, İ̈BF Dergisi, 11(2), 135-160.

Keser, A. ve Karaduman, M. (2014). İş yaşamında yalnızlık algısının örgütsel vatandaşlık davranışı ile ilişkisi ve öğretmenler üzerinde bir araştırma. HAK-İS Uluslararası Emek ve Toplum Dergisi, 3(7), 178-197.

Kiraz, S. (2011). Yabancılaşmanın kökeni üstüne. Felsefe ve Sosyal Bilimler Dergisi. 12, 147-169.

MacCallum, R.C., Browne, M.W. ve Sugawara, H.M. (1996). Power analysis and determination of sample size for covariance structure modeling. Psychological Methods, 1(2), 130-149.

MacKinnon, D.P., Lockwood, C.M., Hoffman, J.M., West, S.G. ve Sheets, V. (2002). A comparison of methods to test mediation and other intervening variable effects. Psychological Methods, 7, 83-104.

Mclean, A. ve Sims, D. (1978). Job enrichment from theoretical poverty: The state of the art and directions for further work. Personnel Review, 7(2), 5-10

Meydan, C.H. ve Şeşen, H. (2011). Yapısal eşitlik modellemesi AMOS Uygulamaları. Ankara: Detay Yayımcilık.

Meyer, J.P., Allen, N.J. ve Smith, C.A. (1993), Commitment to organizations and occupations: Extension and test of a three-component conceptualization. Journal of Applied Psychology, 78, 538-551.

Montgomery, D.C., Peck, E.A. ve Vining, G.G. (2012). Introduction to linear regression analysis. John Wiley \& Sons, Hoboken.

Orçanlı, K., Oktay, E. ve Birgören, B. (2018). Kış sporları merkezlerine farkındalık algısının oluşmasında etkili faktörlerin belirlenmesi. Sosyal Bilimler Araştırma Dergisi, 4(2), 1-19. 
Organ, D.W. (1988). Organizational citizenship behaviors: The good soldier syndrome. Lexington, Massachusetts: Lexington Books.

Örnek, A.Ş. ve Aydın, Ş. (2008). Kriz ve stres yönetimi. Ankara:Detay Yayıncılık. Özdevecioğlu, M. (2003). Örgütsel vatandaşlık davranışı ile üniversite öğrencilerinin bazı demografik özellikleri ve akademik başarıları arasındaki ilişkilerin belirlenmesine yönelik bir araştırma. Erciyes Üniversitesi İ̈BF Dergisi, 20, 117-135.

Özler, N.D. ve Dirican, M. (2014), Örgütlerde yabancılaşma ile tükenmişlik sendromu arasındaki ilişkiyi belirlemeye yönelik bir araştırma. Dumlupinar Üniversitesi Sosyal Bilimler Dergisi, 39.

Özdamar, K. (2013). Paket programlar ile istatistiksel veri analizi. (9. Baskl). Eskişehir: Nisan Kitapevi.

Parsak, G. (2010). Örgütlerde yabancılaşma ve iş tatmini ilişkisi: Çukurova Üniversitesi çalı̧̧anları üzerinde bir uygulama. Çukurova Üniversitesi Sosyal Bilimler Enstitüsü Yüksek Lisans Tezi. Adana.

Penner, L.A., Midili, A.R. ve Kegelmeyer, J. (1997). Beyond job attitudes: A personality and social psychology perspective on the causes of organizational citizenship behavior. Human Performance, 10(2), 111-131.

Podsakoff, P.M., MacKenzie, S.B., Paine, J.B., ve Bachrach, D.G. (2000) Organizational citizenship behaviors: A critical review of the theoretical and empirical literature and suggestions for future research. Journal of Management, 26(3), 513-563.

Preacher, K.J. ve Hayes, A.F. (2004). SPSS and SAS procedures for estimating indirect effects in simple mediation models. Behavior Research Methods, Instruments, and Computers, 36, 717-731.

Salihoğlu, G. H. (2014). Örgütsel yabancılaşma. Organizasyon ve Yönetim Bilimleri Dergisi, 6(2), 1-11.

Saleem, S., Shaheen, W.A. ve Saleem, R. (2012). The impact of job enrichment and job enlargement on employee satisfaction keeping employee performance as intervening variable: A Correlational study from pakistan. Kuwait Chapter of the Arabian Journal of Business and Management Review, 1(9), 145.

Seeman, M. (1983). Alienation motifs in contemporary theorizing: The hidden continuity of the classic themes. Social Psychology Quarterly, 46(3), 171-184.

Shantz, A., Alfes, K., Bailey, C. ve Soane, E. (2017). Drivers and outcomes of work alienation: Reviving a concept. Journal of Management Inquiry, 24(4), 382-393 
Shepard, J.M. (1971). Automation and alienation: A study of office and factory workers, Cambridge:The M.I.T.

Sezgin, F. (2005). Örgütsel vatandaşlık davranışları: Kavramsal bir çözümleme ve okul açısından bazı çıkarımlar. Gazi Eğitim Fakültesi Dergisi, 25(1), 317-339.

Somech, A. ve Drach-Zahavy, A. (2000). Understanding extra-role behavior in schools: The relationships between job satisfaction, sense of efficacy, and teachers' extra-role behavior. Teaching and Teacher Education, 16, 649-659.

Şanal, M. (2013). Örgütsel vatandaşlık davranışının işletmeler açısından önemi, Ç.Ü. Sosyal Bilimler Enstitüsü Dergisi, 22(1), 529-538.

Şimşek, M.Ş., Akgemci, T., Çelik, A. ve Fettahlıŏlu, T. (2006). Örgütlerde yabancılaşmanın yönetimi araştırması. Selçuk Üniversitesi Sosyal Bilimler Enstitüsü Dergisi, 15, 569-587

Şimşek, M.Ş., Akgemci, T. ve Çelik, A. (2008). Davranış bilimlerine giriş ve örgütlerde davranış. Ankara: Gazi Kitabevi.

Şimşek, Ö.F. (2007). Yapısal eşitlik modellemesine giriş: Temel ilkeler ve LISREL uygulamaları. Ankara: Ekinoks Yayınları.

Tanış, A. ve Turunç, Ö. (2017). İş karakteristikleri, işyeri güvenliği ve örgütsel vatandaşlık ilişkileri: Kültürler arası bir çalışma. Uluslararası İktisadi ve İdari Bilimler Dergisi, 3(3), 1-24.

Tanrıverdi, H. ve Kılıç, N. (2016). Algılanan örgütsel destek ve örgütsel yabancılaşma arasındaki ilişkinin incelenmesi. http://www.sdergi.hacettepe.edu.tr adresinden erişilmiştir.

Tufail, M.S., Bashir, M. ve Shoukat.N. (2017). Impact of job design on employee's organizational citizenship behavior and counterproductive work behavior in the banking sector of Fa1salabad. City University Research Journal, Special Issue: AIC, Malaysia, 225-235.

Tummers, L. ve Dulk, L. (2013). The effects of work alienation on organisational commitment. Work effort and work-to-family enrichment. Journal of Nursing Management, 21(6), 1-21.

Turgut, H., Tokmak, İ. ve Ateş, M.F. (2016). The moderating role of leadermember exchange on the relationship between emotional labor with job satisfaction or turnover intention. International Journal of Business and Management, 11(12), 83-96. 
Turhan, Ö. (2019). Duygusal emeğin örgütsel vatandaşlı üzerindeki etkisinde örgütsel yaşamda yalnızlı̆̆ın aracı rolü: Bir araştırma. Doktora Tez, İstanbul Kültür Üniversitesi Sosyal Bilimler Enstitüsü. İstanbul.

Tutar, H. (2010). İşgören yabancılaşması ve örgütsel sağlık ilişkisi: Bankacılık Sektöründe Bir Uygulama. Ankara Üniversitesi SBF Dergisi, 65(1), 175-204. Yalçın, İ. ve Seçkin, C. K. (2014). Örgütsel yabancılaşma olgusunun iş tatmini üzerine etkisi: Niğde ilinde bir araştırma. KMÜ Sosyal ve Ekonomik Araştırmalar Dergisi, 16(26), 86-94.

Yeniçeri, Ö. (2009). Örgütlerde çatışma ve yabancılaşma yönetimi. İstanbul: Iq Kültür Sanat Yayıncilık.

Waltz, S.E. (1982). Antidotes for a social Malaise: Alienation, efficacy, and participation in Tunisia, Comparative Politics, 14(2), 127-147.

Zengin, Y. ve Kaygın, E. (2016). Örgütsel adalet ve örgütsel yabancılaşma arasındaki ilişkiyi belirlemeye yönelik bir araştırma. Akademik Bakış Dergisi, 56, 391-415.

\section{Kaynakça Bilgisi / Citation Information}

Eroğluer, K. (2020). Örgütsel vatandaşlık ve örgütsel yabancilaşma arasındaki ilişkide iş zenginleştirmenin aracılık etkisi. OPUS-Uluslararası Toplum Araştırmaları Dergisi, 15(21), 323-355. DOI: 10.26466/opus.620697 